\title{
Endogenous synthesis of milk oleic acid in dairy ewes: In vivo measurement using ${ }^{13} \mathrm{C}$-labeled stearic acid
}

\author{
P. G. Toral, ${ }^{1}$ P. Frutos, D. Carreño, and G. Hervás \\ Instituto de Ganadería de Montaña (CSIC-Universidad de León), Finca Marzanas s/n, 24346 Grulleros, León, Spain
}

\begin{abstract}
The use of stable isotopes is a reliable and risk-free alternative to radioactive tracers for directly examining in vivo fatty acid (FA) metabolism. However, very limited information is available in ruminants, and none is available in sheep. Therefore, we conducted an experiment in dairy ewes to determine, for the first time in this species, the uptake, $\Delta^{9}$-desaturation, and secretion of ${ }^{13} \mathrm{C}$-labeled stearic acid (SA) into milk with the aim of measuring in vivo endogenous synthesis of milk oleic acid (OA) and stearoyl-CoA desaturase activity. Six lactating Assaf ewes fed a total mixed ration (forage:concentrate ratio $=30: 70$ ) received an intravenous injection of $2 \mathrm{~g}$ of ${ }^{13} \mathrm{C}$-labeled SA. At $-24,-15$, $0,4,8,12,16,20,24,36,48,60$, and $72 \mathrm{~h}$ postinjection (p.i.), milk yield was recorded and milk samples were collected to examine fat concentration and FA composition, including compound-specific isotope analysis of SA and OA by gas chromatography-combustion isotope ratio mass spectrometry. Over the p.i. period, the SA proportion ranged from 7.6 to $8.3 \%$ of total FA, with a maximum ${ }^{13} \mathrm{C}$ enrichment of $1.9 \%$, whereas $\mathrm{OA}$ was more abundant (14.3-15.4\% of total FA) and had lower ${ }^{13} \mathrm{C}$ enrichments (up to $0.69 \%$ ). On average, $15 \%$ of the isotopic tracer was transferred to milk within 72 h p.i., and 47 to $50 \%$ of the SA taken up by the mammary gland would have been desaturated to OA. The proportion of oleic acid being synthesized endogenously was estimated to represent between 48 and $57 \%$ of the amount secreted in milk. Further research under different dietary conditions is recommended.
\end{abstract}

Key words: $\Delta^{9}$-desaturation, sheep, stable isotope, stearoyl-CoA desaturase

\section{INTRODUCTION}

To comply with industry and consumer demands for potentially healthier foods, considerable research effort

Received October 3, 2016.

Accepted March 29, 2017.

${ }^{1}$ Corresponding author: pablo.toral@csic.es has been put into decreasing the concentration of some saturated fatty acids (FA; e.g., 12:0, 14:0, and 16:0) and increasing that of unsaturated FA in ruminant-derived products (Shingfield et al., 2008b). In this regard, the unsaturated to saturated FA ratio in milk fat depends to a large extent on the activity of stearoyl-CoA desaturase (SCD), with the substrate-product pairs of this enzyme adding up to approximately 75 to $80 \%$ of total milk FA (Mosley and McGuire, 2007; Glasser et al., 2008; Frutos et al., 2014). Furthermore, by catalyzing $\Delta^{9}$-desaturation, the SCD not only contributes to the synthesis of desirable FA, such as cis-9 18:1 (oleic acid; OA) and cis-9,trans-11 CLA, but also determines physical properties of milk fat that have relevant physiological and technological implications (Bernard et al., 2013).

Quantification of endogenous synthesis of milk FA derived from $\Delta^{9}$-desaturation initially relied on the use of radioactive tracers (e.g., Annison et al., 1967; Bickerstaffe and Annison, 1970) and then on indirect methods developed to estimate this enzymatic activity, including inhibition of the SCD (Griinari et al., 2000; Taugbøl et al., 2008; Bichi et al., 2012) and comparison of duodenal and milk FA flows (Glasser et al., 2008). The use of stable isotopes emerged more recently as a reliable and risk-free alternative to radioactive tracers for directly measuring in vivo $\Delta^{9}$-desaturation, even though studies in lactating ruminants are still very scarce. We are aware of only 3 reports - 1 in cows (Mosley et al., 2006) and 2 in goats (Bernard et al., 2010; Toral et al., 2012) - involving the administration of ${ }^{13} \mathrm{C}$-labeled trans-11 18:1 (vaccenic acid; VA). There is also a preliminary work, so-called by the authors (Mosley and McGuire, 2007), using ${ }^{13}$ C-labeled 18:0 (stearic acid; SA) as precursor of OA in dairy cattle. However, although SA is the preferred substrate of SCD (Bernard et al., 2013) and the study by Mosley and McGuire (2007) aimed to provide the basis for later trials, we have not found any related research on ${ }^{13} \mathrm{SA}$ metabolism in the literature, nor does there seem to be any publication on the use of stable carbon isotopes in sheep. Therefore, we conducted an experiment in dairy ewes to determine, for the first time in this species, the uptake, $\Delta^{9}$-desaturation, and 
secretion of ${ }^{13} \mathrm{SA}$ into milk with the aim of measuring in vivo endogenous synthesis of milk OA and SCD activity.

\section{MATERIALS AND METHODS}

\section{Animals, Experimental Design, and Management}

All experimental procedures were approved and completed in accordance with the Spanish Royal Decree $53 / 2013$ for the protection of animals used for experimental purposes. Six lactating Assaf ewes with similar milk yield $(1.9 \pm 0.06 \mathrm{~kg} / \mathrm{d})$, milk fat concentration $(5.2 \pm 0.14 \%)$, BW $(79.9 \pm 3.78 \mathrm{~kg})$, and DIM $(122 \pm$ 3.6) before ${ }^{13} \mathrm{SA}$ injection were used. Sheep were housed in individual tie stalls and fed ad libitum a TMR formulated from alfalfa hay and concentrates (see Table 1 for ingredients). Ewes were milked twice daily in a 10-stall milking parlor, and clean drinking water was always available.

After $21 \mathrm{~d}$ of adaptation to the TMR, each sheep received a single dose of $2 \mathrm{~g}$ of ${ }^{13} \mathrm{SA}\left(\left[1{ }^{13} \mathrm{C}\right] 18: 0,99 \%\right.$ atom $\%{ }^{13} \mathrm{C} ; 299162$, Sigma-Aldrich, Madrid, Spain) suspended in an emulsion of $1 \mathrm{~g}$ of Simulsol 5817 (Seppic, Paris, France) and 0.5 mL of glycerol $(\geq 99 \%$; Sigma-Aldrich) in $200 \mathrm{~mL}$ of saline solution $(0.9 \% \mathrm{NaCl}$ wt/vol; B. Braun Medical SA, Barcelona, Spain). The

Table 1. Formulation and chemical composition of the TMR

\begin{tabular}{|c|c|c|}
\hline Item & Mean $^{1}$ & SEM \\
\hline \multicolumn{3}{|l|}{ Ingredient, $\mathrm{g} / \mathrm{kg}$ of fresh matter } \\
\hline Dehydrated alfalfa hay (particle size $>4 \mathrm{~cm}$ ) & 300 & - \\
\hline Whole barley grain & 210 & - \\
\hline Whole corn grain & 190 & - \\
\hline Soybean meal solvent $44 \% \mathrm{CP}$ & 160 & - \\
\hline Sugar beet pulp (pellets) & 70 & - \\
\hline Molasses (liquid) & 40 & - \\
\hline Mineral supplement ${ }^{2}$ & 28 & - \\
\hline Vitamin supplement $^{3}$ & 2 & - \\
\hline \multicolumn{3}{|l|}{ Chemical composition, $\mathrm{g} / \mathrm{kg}$ of DM } \\
\hline $\mathrm{OM}$ & 900 & 10.0 \\
\hline $\mathrm{CP}$ & 195 & 7.3 \\
\hline $\mathrm{NDF}$ & 215 & 6.4 \\
\hline $\mathrm{ADF}$ & 119 & 5.1 \\
\hline Starch & 235 & 5.2 \\
\hline Total fatty acids & 24.0 & 1.46 \\
\hline $16: 0$ & 4.4 & 0.22 \\
\hline 18:0 & 0.9 & 0.03 \\
\hline $18: 1$ cis-9 & 4.2 & 0.28 \\
\hline $18: 2 n-6$ & 11.9 & 0.85 \\
\hline $18: 3 n-3$ & 2.1 & 0.22 \\
\hline
\end{tabular}

${ }^{2}$ Declared as containing the following $(\mathrm{g} / \mathrm{kg})$ : $\mathrm{CaCO}_{3}, 556 ; \mathrm{Ca}_{2} \mathrm{HPO}_{4}$, $222 ; \mathrm{NaCl}, 222$.

${ }^{3}$ Vitafac Ovino $0.2 \%$ AC (DSM Nutritional Products SA, Madrid, Spain). Declared as containing the following: vitamin A, 4,000,000 IU/ $\mathrm{kg}$; vitamin $\mathrm{D}_{3}, 1,000,000 \mathrm{IU} / \mathrm{kg}$; vitamin E, $5 \mathrm{~g} / \mathrm{kg} ; \mathrm{Fe}, 17.5 \mathrm{~g} / \mathrm{kg} ; \mathrm{Mn}$, $20 \mathrm{~g} / \mathrm{kg}$; Co, $50 \mathrm{mg} / \mathrm{kg}$; I, $250 \mathrm{mg} / \mathrm{kg} ; \mathrm{Zn}, 15 \mathrm{~g} / \mathrm{kg}$; Se, $100 \mathrm{mg} / \mathrm{kg}$; sepiolite, $100 \mathrm{~g} / \mathrm{kg}$; Ca, $26.2 \mathrm{~g} / \mathrm{kg}$; and $\mathrm{Mg}, 6.15 \mathrm{~g} / \mathrm{kg}$. mixture was sonicated at $24 \mathrm{kHz}$ and $150 \mathrm{~W}$ for $1 \mathrm{~min}$ to ensure thorough mixing. The dose was delivered immediately after the morning milking by continuous jugular infusion for $30 \mathrm{~min}$.

\section{Measurements and Sampling Procedures}

Representative samples of the TMR were collected, stored at $-30^{\circ} \mathrm{C}$, and freeze dried before chemical analysis. At $-24,-15,0,4,8,12,16,20,24,36,48,60$, and 72 $\mathrm{h}$ after injection of the ${ }^{13} \mathrm{SA}$ (postinjection; p.i.), milk yield was recorded and individual milk samples were collected. One aliquot preserved with bronopol (D\&F Control Systems Inc., San Ramon, CA) was stored at $4^{\circ} \mathrm{C}$ until analyzed for fat concentration, whereas another aliquot of untreated milk was stored at $-30^{\circ} \mathrm{C}$ for FA composition analysis and ${ }^{13} \mathrm{C}$ enrichment. For these latter analyses, samples collected at -15 and $0 \mathrm{~h}$ were mixed according to yield and the pool was used as the 0 -h sample. The same was done for samples collected at 60 and $72 \mathrm{~h}$ p.i. (i.e., they were pooled and considered the 72 -h sample).

\section{Laboratory Analysis}

Diets and Orts. Dry matter concentration was determined in the TMR and orts (ISO, 1999a). The TMR was also analyzed for ash (ISO, 2002), CP (ISO, 2009), and starch (K-TSTA kit; Megazyme International Ireland, Wicklow, Ireland). The NDF and ADF were determined using an Ankom $^{2000}$ fiber analyzer (Ankom Technology Corp., Macedon, NY; Ankom, 2006a,b); the former was assayed with sodium sulfite and $\alpha$-amylase, and both were expressed with residual ash. The FAME of lipid in freeze-dried TMR samples were prepared in a 1-step extraction-transesterification procedure (Shingfield et al., 2003) with tridecanoic acid (Sigma-Aldrich) as an internal standard. The methyl esters were separated and quantified by GC-flame ionization detector (GC-FID) as outlined in Toral et al. (2016) using a temperature gradient program (Shingfield et al., 2003). Peaks were identified based on retention time comparisons with commercially available standards (GLC463, Nu-Chek Prep, Elysian, MN; 18919-1AMP Supelco, Sigma-Aldrich).

Milk. Fat concentration was determined by infrared spectrophotometry (ISO, 1999b) using a MilkoScan FT6000 (Foss, Hillerød, Denmark). Lipid in $1 \mathrm{~mL}$ of milk was extracted and converted to FAME by basecatalyzed transesterification (Shingfield et al., 2003). The total FAME profile was determined by GC-FID using the same temperature gradient program applied for the analysis of TMR samples, but 18:1 isomers were further resolved in a separate analysis under isothermal 
conditions (Shingfield et al., 2003). Peaks were identified based on retention time comparisons with commercially available standards (GLC463, U-37-M, U-43-M, U-45-M, and U-64-M, Nu-Chek Prep; 18919-1AMP Supelco, L6031, L8404, and O5632, Sigma-Aldrich; and 11-1600-8, 20-2024-1, 20-2210-9, 20-2305-1-4, 21-12117, 21-1413-7, 21-1614-7, 21-1615-7, and BR mixtures 2 and 3, Larodan, Solna, Sweden) and reference milk samples (Bichi et al., 2013).

Preliminary analysis of ${ }^{13} \mathrm{SA}$ and ${ }^{13} \mathrm{OA}$ concentrations in milk FAME was conducted by GC-MS (Varian CP3800 GC system equipped with a Varian 1200L quadrupole mass detector; Varian Inc., Palo Alto, CA), but the resolution failed to detect increases in ${ }^{13} \mathrm{C}$ percentage above basal levels. Therefore, compound-specific isotope analysis was performed at the Stable Isotopes Laboratory of the Interdepartmental Research Service (SIdI, Autonomous University of Madrid, Spain) using a GC-combustion isotope ratio MS (GC-C-IRMS) system (Thermo Scientific, Bremen, Germany) comprising a Trace GC Ultra gas chromatograph coupled to a Delta V Advantage isotope ratio mass spectrometer through a GC Combustion III interface maintained at $940^{\circ} \mathrm{C}$. The FAME were separated on a $30-\mathrm{m}$ capillary column $(0.25 \mathrm{~mm}$ i.d., $0.25 \mu \mathrm{m}$ film thickness; J\&W DB-5, Agilent, Santa Clara, CA) with helium as the carrier gas $(180 \mathrm{kPa} ; 1.2 \mathrm{~mL} / \mathrm{min})$. The injector (split ratio of $1: 20)$ was maintained at $260^{\circ} \mathrm{C}$. After sample injection, column temperature was held at $150^{\circ} \mathrm{C}$ for 5 min, increased at a rate of $1^{\circ} \mathrm{C} / \mathrm{min}$ to $200^{\circ} \mathrm{C}$, and then increased at a rate of $10^{\circ} \mathrm{C} / \mathrm{min}$ to a final temperature of $300^{\circ} \mathrm{C}$ that was maintained for $10 \mathrm{~min}$. Identifications were based on retention time comparisons with commercially available standards [299162 and 490423 (Sigma-Aldrich) and the same FAME mixtures used for GC-FID analysis] and reference milk samples (Bichi et al., 2013). The ${ }^{13} \mathrm{C}$ percentage in the methanol employed for FA transesterification was also determined by GC-C-IRMS following the same procedure applied for the analysis of milk SA and OA methyl esters. Results were used to correct for the isotopic shift due to the extra methyl group in FAME.

\section{Calculations}

Calculations to determine the percentage of milk OA originating from $\Delta^{9}$-desaturation were based on previous reports in lactating ruminants (Mosley et al., 2006; Bernard et al., 2010). First, total milk FA yield was computed as outlined by Glasser et al. (2007). In brief, the mean molecular weight of the FA was used to estimate the proportion of FA in milk triglycerides, which was subsequently multiplied by milk fat yield. Milk FA yield was then used to calculate the amount $(\mathrm{g})$ of SA and OA secreted in milk at each postinjection sampling period (Table 2). To account for the natural levels of ${ }^{13} \mathrm{C}$ and determine the proportion of ${ }^{13} \mathrm{SA}$ and ${ }^{13} \mathrm{OA}$ that would actually derive from the injected labeled FA, the mean ${ }^{13} \mathrm{C}$ percentage of samples taken before ${ }^{13} \mathrm{SA}$ injection (i.e., -24 and $0 \mathrm{~h}$ samples) was subtracted from the ${ }^{13} \mathrm{C}$ percentage of each sample (see Table 2 for details). These values were used to determine the amounts of ${ }^{13} \mathrm{SA}$ and ${ }^{13} \mathrm{OA}$ secreted in milk postinjection $(\mathrm{g})$ deriving from the isotopic tracer. These data were then employed to calculate the proportion of SA desaturated to OA in vivo, the fraction of milk OA synthesized endogenously, and the percentage of the injected labeled FA secreted into milk lipids (Table 2). For variables expressed as a percentage, namely milk fat and milk FA concentrations, data correspond to the mean percentage weighted by milk yield or milk FA yield, respectively, at each sampling time.

\section{RESULTS}

The maximum enrichment of ${ }^{13} \mathrm{SA}$ in milk $(1.90 \%$ of total SA) was observed in samples collected at $16 \mathrm{~h}$ p.i. Then, after a relatively rapid decline until $48 \mathrm{~h}$ p.i., the decrease in ${ }^{13} \mathrm{SA}$ concentration was less pronounced (Figure 1). On the contrary, no clear peak in milk ${ }^{13} \mathrm{OA}$ enrichment was found. The greatest values $(\sim 0.69 \%$ of total OA) were obtained between 16 and $24 \mathrm{~h}$ p.i. and were followed by a slow decline. Therefore, all calculations described in Table 2 were conducted using data of sampling not only from injection to $72 \mathrm{~h}$ p.i. but also from $16 \mathrm{~h}$ p.i. or until $48 \mathrm{~h}$ p.i.

Data of animal performance and milk FA used to calculate the endogenous synthesis of milk OA are reported in Table 3. In addition, DMI averaged 1,921 \pm $79.4 \mathrm{~g} / \mathrm{d}$, and no changes were detected during the experiment. Milk fat concentration was relatively stable throughout the postinjection period (on average, 6.7\% of raw milk), and total milk FA percentage represented $94.2 \%$ of milk fat. The SA percentage ranged from 7.6 to $8.3 \%$ of total FA, with a mean of 1.8 to $2.1 \%$ as ${ }^{13} \mathrm{SA}$, whereas OA was more abundant $(14.3-15.4 \%$ of total FA) and had lower ${ }^{13} \mathrm{C}$ percentages (approximately $1.5-1.6 \%$ ). Mean ${ }^{13} \mathrm{SA}$ and ${ }^{13} \mathrm{OA}$ percentages in preinjection samples were 1.074 and $1.075 \%$, respectively (data not shown in tables). In the GC-FID analysis, the OA peak area contained an estimated proportion of just over $1 \%$ of trans-13+14 18:1 ( $\sim 0.15 \%$ of total FA). In the GC-C-IRMS analysis, it presumably coeluted with 18:3n-3 and minor 18:2 isomers (trans-9,trans-12, trans-11,trans-15, and trans-9,cis-12 18:2), which would represent less than $3.7 \%$ of the OA peak area $(\sim 0.55 \%$ of total FA). Assuming that the coeluting isomers had the same natural ${ }^{13} \mathrm{C}$ level as preinjection samples, reported 


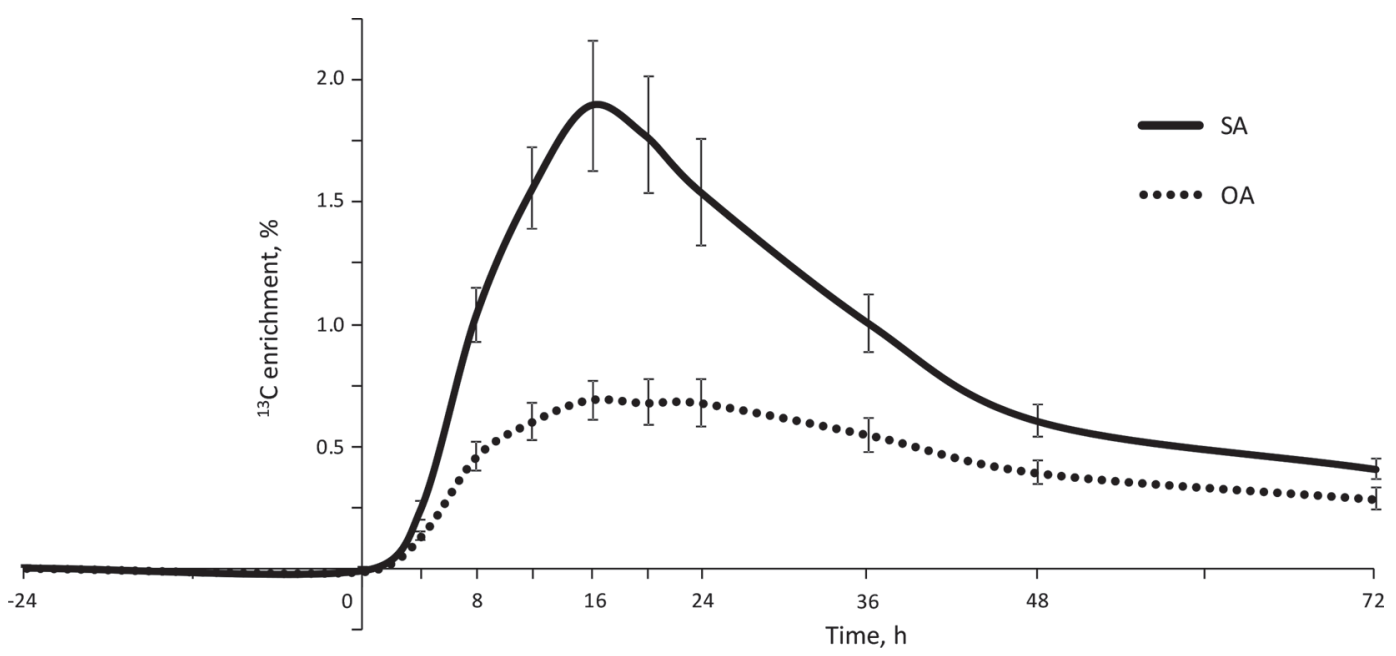

Figure 1. Enrichment of ${ }^{13} \mathrm{C}$ in 18:0 (stearic acid; SA) and cis-9 18:1 (oleic acid; OA) in milk fat from dairy ewes (n =6) receiving an intravenous injection of $2 \mathrm{~g}$ of $\left[1-{ }^{13} \mathrm{C}\right] 18: 0$ at time 0 . Error bars represent the SEM. The 0-h samples correspond to the pool of milk collected at -15 and $0 \mathrm{~h}$, and the 72-h samples correspond to the pool of milk collected at 60 and $72 \mathrm{~h}$ (all of them were composited according to yield).

${ }^{13} \mathrm{OA}$ concentrations would then be underestimated by approximately 1.1 to $1.2 \%$ (e.g., 1.558 vs. $1.573 \%$ for the period from injection to $48 \mathrm{~h}$ p.i.).

The ${ }^{13} \mathrm{C}$ enrichments, which were used to calculate the secretion of labeled FA deriving from the injected ${ }^{13} \mathrm{SA}$, are shown in Table 4 (equations 5 and 6 ). On average, $15 \%$ of this isotopic tracer was transferred to milk within $72 \mathrm{~h}$ p.i., and between 47 and $49 \%$ of the SA would have been desaturated to milk OA in the periods until 48 and $72 \mathrm{~h}$ p.i. Values of SA $\Delta^{9}$-desaturation were only marginally higher when calculations were conducted from the point of maximum ${ }^{13} \mathrm{C}$ enrichment (47 and 50\% for 16-48 and 16-72 h p.i., respectively). Similarly, the proportion of milk OA estimated to derive from endogenous synthesis was $48 \%$ when the first $48 \mathrm{~h}$ p.i. were considered and $52 \%$ when using the 72 h p.i. period, and was slightly greater for the 16 to 48 and 16 to $72 \mathrm{~h}$ p.i. periods (52 and $57 \%$, respectively).

Table 2. Calculations to determine the percentage of cis-9 18:1 (oleic acid; OA) in milk originating from 18:0 (stearic acid; SA) in dairy ewes receiving an intravenous injection of $2 \mathrm{~g}$ of $\left[1{ }^{13} \mathrm{C}\right] 18: 0$

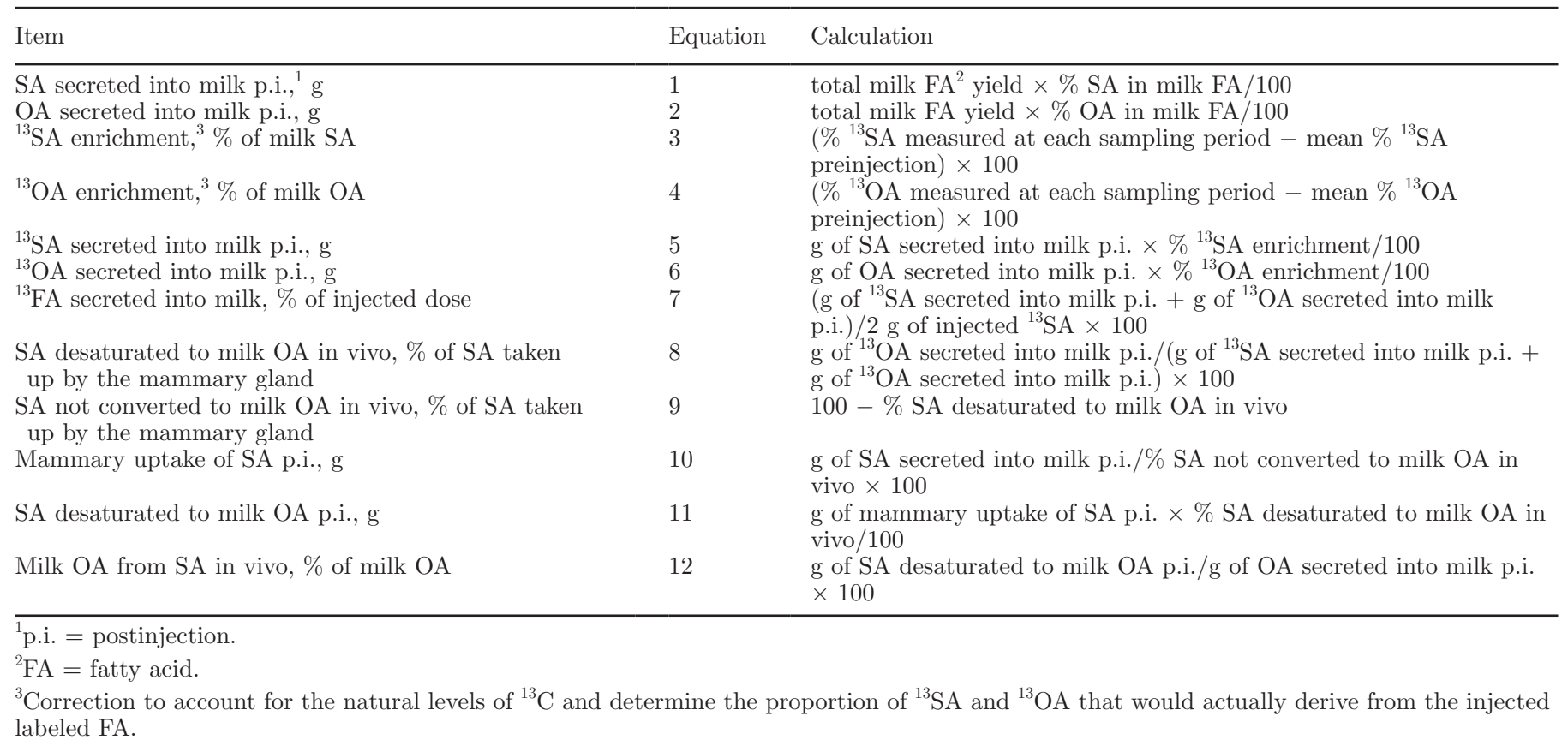


Table 3. Animal performance and milk fatty acid (FA) data used for calculations to determine the percentage of milk cis-9 18:1 (oleic acid; OA) originating from 18:0 (stearic acid; SA) desaturation in dairy ewes $(\mathrm{n}=6)$ receiving an intravenous injection of $2 \mathrm{~g}$ of $\left[1-{ }^{13} \mathrm{C}\right] 18: 0$

\begin{tabular}{|c|c|c|c|c|c|c|c|c|}
\hline \multirow[b]{2}{*}{ Item } & \multicolumn{2}{|c|}{ Injection to $48 \mathrm{~h} \mathrm{p.i.}{ }^{1}$} & \multicolumn{2}{|c|}{ Injection to $72 \mathrm{~h}$ p.i. } & \multicolumn{2}{|c|}{16 to $48 \mathrm{~h}$ p.i. } & \multicolumn{2}{|c|}{16 to $72 \mathrm{~h}$ p.i. } \\
\hline & Mean & SEM & Mean & SEM & Mean & SEM & Mean & SEM \\
\hline Milk fat, $\%$ of raw milk & 6.80 & 0.265 & 6.69 & 0.232 & 6.71 & 0.411 & 6.62 & 0.298 \\
\hline Total milk fat yield, $\mathrm{g}$ & 169.6 & 11.24 & 266.7 & 16.75 & 110.2 & 9.61 & 207.3 & 14.82 \\
\hline Total FA, $\%$ of milk fat & 94.19 & 0.047 & 94.21 & 0.053 & 94.20 & 0.059 & 94.21 & 0.061 \\
\hline Total FA yield, $\mathrm{g}$ & 159.8 & 10.52 & 251.2 & 15.68 & 103.8 & 9.01 & 195.2 & 13.88 \\
\hline${ }^{13} \mathrm{SA}, \%$ of milk SA & 2.077 & 0.1068 & 1.861 & 0.0790 & 2.070 & 0.1141 & 1.795 & 0.0799 \\
\hline${ }^{13} \mathrm{OA}, \%$ of milk OA & 1.558 & 0.0633 & 1.485 & 0.0551 & 1.592 & 0.0682 & 1.484 & 0.0579 \\
\hline
\end{tabular}

${ }^{1}$ p.i. $=$ postinjection.

\section{DISCUSSION}

Despite the convenience of using isotopic tracers to examine FA metabolism, very few studies have applied this methodology in ruminants (Mosley et al., 2006; Bernard et al., 2010; Toral et al., 2012). This work provides the first assessment of the in vivo metabolism of ${ }^{13} \mathrm{C}$-labeled FA in ewes.

Our findings include some relevant differences compared with earlier studies in bovines and caprines. First, milk ${ }^{13} \mathrm{C}$ enrichments were lower than those observed for the administration of ${ }^{13} \mathrm{C}$-labeled FA (either ${ }^{13} \mathrm{SA}$ or ${ }^{13} \mathrm{VA}$ ) in cows and goats (Mosley et al., 2006; Mosley and McGuire, 2007; Bernard et al., 2010), although comparisons are complicated because data reported by Mosley and McGuire (2007) and Bernard et al. (2010) do not allow the estimation of transfer efficiencies of isotopic tracers into milk. When compared with results by Mosley et al. (2006), we observed a lower transfer efficiency of ${ }^{13} \mathrm{SA}$ into sheep milk (up to $15 \%$ for the 72 -h p.i. period) than that estimated for ${ }^{13} \mathrm{C}$-labeled VA in cow milk ( $\sim 33 \%$ after $24 \mathrm{~h}$ of administration). However, the available information is not sufficient to determine whether variations are linked to metabolic differences between ruminant species or to studied FA (SA and VA), which would merit further research. Moreover, our transfer efficiency was lower than the range reported by Glasser et al. (2008) for the sum of SA and OA in cows (20-90\% of their duodenal flow).

Low ${ }^{13} \mathrm{SA}$ and ${ }^{13} \mathrm{OA}$ percentages were expected given the expression of ${ }^{13} \mathrm{C}$ enrichments as relative proportions of the target FA and the high contribution of this FA pair to milk lipids (approximately $22-23 \%$ of total FA in our samples). In our study, the amount of injected ${ }^{13} \mathrm{SA}$ represented $3.6 \%$ of the $\mathrm{SA}+\mathrm{OA}$ secreted in milk within $72 \mathrm{~h}$ p.i., which is a lower proportion than the ${ }^{13} \mathrm{VA}$ delivered to goats $(\sim 10 \%$ of the estimated milk substrate + product output in the same postinjection period; Bernard et al., 2010). Mosley and McGuire (2007) infused the ${ }^{13} \mathrm{C}$-labeled FA into the duodenum or abomasum of cows rather than intravenously. Therefore, we estimated the corresponding dose of ${ }^{13} \mathrm{SA}$ on the basis of potentially absorbed quantities, assuming a mean SA digestibility of $74 \%$ (Loften et al., 2014). Surprisingly, when the proportion of ${ }^{13} \mathrm{C}$-labeled SA represented approximately $3.5 \%$ of milk $\mathrm{SA}+\mathrm{OA}$ yield, no enrichment was detected by GC-MS by Mosley and McGuire (2007), whereas increasing the dose to $7.8 \%$ enabled the detection of ${ }^{13} \mathrm{SA}$ enrichments of up to $5 \%$. Similarly, we failed to detect ${ }^{13} \mathrm{C}$ concentrations over basal levels in a preliminary GC-MS analysis of our milk samples, which led us to switch to GC-C-IRMS, a methodology offering greater accuracy and precision for determining isotope distribution at low abundance levels (Meier-Augenstein, 1999). As suggested by Mosley and McGuire (2007), the high cost of ${ }^{13} \mathrm{C}$-labeled FA and the putative alteration of in vivo FA pools when high doses are used make the ability to detect ${ }^{13} \mathrm{C}$ enrichments with minimal input actually desirable. In this respect, our findings would confirm GC-C-IRMS as the method of choice when the ratio between the isotopic tracer and milk FA yield is expected to be low.

The second discrepancy between our results and those from earlier investigations was the temporal changes in ${ }^{13} \mathrm{C}$ concentrations in milk. A longer time period was needed to reach the maximum ${ }^{13} \mathrm{C}$ enrichment in ewes (16 h p.i.) compared with goats (10-14 h p.i.; Bernard et al., 2010) and, especially, with cows ( $8 \mathrm{~h}$ after bolus infusion of ${ }^{13} \mathrm{C}$-labeled FA in the abomasum; Mosley et al., 2006; Mosley and McGuire, 2007). In bovines, ${ }^{13} \mathrm{C}$ enrichments declined rapidly and were below detectable levels $(\sim 0.5 \%$ in their conditions) at 24 to $36 \mathrm{~h}$ postinfusion (Mosley et al., 2006; Mosley and McGuire, 2007), whereas in goats, decreases in ${ }^{13} \mathrm{C}$ enrichments to undetectable values were slower and progressive over 72 h p.i. (Bernard et al., 2010). In our study, the greatest 
decline in ${ }^{13} \mathrm{SA}$ enrichment, observed between 16 and 48 $\mathrm{h}$ samplings, was also slower than that reported in cows (Mosley and McGuire, 2007). However, despite the low concentrations of ${ }^{13} \mathrm{SA}$ and ${ }^{13} \mathrm{OA}$ detected afterward $(0.4$ and $0.3 \%$, respectively, at $72 \mathrm{~h}$ p.i.), the high sensitivity of GC-C-IRMS still allowed for reliable ${ }^{13} \mathrm{C}$ quantifications. The scarcity of data in the literature does not enable us to elucidate the reasons for inconsistencies in labeled FA secretion over time, but these might lie in interspecies variation in mammary metabolism given the well-established differences between ruminants in the transport kinetics of other molecules, such as xenobiotics, into milk (e.g., Ziv et al., 1995; Shem-Tov et al., 1997). The influence of energy balance and potential interspecies differences in FA uptake in adipose tissues (Vernon, 1980; Chilliard et al., 2005) might also help explain these results.

Dissimilarities in the temporal profile of ${ }^{13} \mathrm{C}$ enrichment in milk would be relevant because of their influence on the selection of sampling periods to quantify the endogenous synthesis of milk FA deriving from SCD activity. In this regard, Mosley et al. (2006) made their calculations in cows between 8 and $24 \mathrm{~h}$ postinfusion, corresponding to time points when ${ }^{13} \mathrm{C}$ enrichment in milk peaked or was minimum but still detectable. In goats, Bernard et al. (2010) computed the measurements conducted from the time of injection to $24 \mathrm{~h}$ later, when ${ }^{13} \mathrm{C}$ enrichment had declined to approximately its midpoint. Given the absence of references in sheep and to try to facilitate the comparison with data from other studies, we calculated all parameters for time periods starting immediately after injection or at $16 \mathrm{~h}$ p.i. and ending 48 or $72 \mathrm{~h}$ p.i. (Table 4), which resulted in only modest dissimilarities as detailed in the Results section.

Nevertheless, comparisons of reported proportions of directly measured endogenous OA synthesis are rather complicated given that only 2 in vivo assays on this subject have been performed and that they were conducted in caprine and bovine (Annison et al., 1967; Mosley and McGuire, 2007). Furthermore, betweenspecies differences in mammary lipogenesis have been pointed out in several studies (e.g., Tsiplakou et al., 2009; Shingfield et al., 2013; Toral et al., 2015a). The preliminary nature of the work by Mosley and McGuire (2007) must also be considered, as a single cow was used for the ${ }^{13} \mathrm{SA}$ infusions. In addition, they observed a significant variation in endogenous $\mathrm{OA}$ synthesis when ${ }^{13} \mathrm{SA}$ was administrated as a bolus or continuous abomasal infusion (74 and 43\%, respectively). The underlying reasons for this inconsistency are not readily apparent but might be related not only to low ${ }^{13} \mathrm{C}$ enrichments during the continuous infusion and associated limitations of the GC-MS analysis but also, according 
to the authors, to matters related to SA digestibility (Mosley and McGuire, 2007). Caution should also be taken when comparing results in the current study with proportions of endogenous milk OA $(80-84 \%)$ in the study by Annison et al. (1967), in which radiolabeled $\left[\mathrm{U}^{14} \mathrm{C}\right] \mathrm{SA}$ was administered to a single goat.

Indirect estimations of in vivo milk OA synthesis are available in dairy ewes through the inhibition of SCD activity by means of sterculic acid or cobalt-acetate administration (Bichi et al., 2012; Frutos et al., 2014; Toral et al., 2015b) as well as in bovines using similar techniques (Corl et al., 2001; Shingfield et al., 2008a; Taugbøl et al., 2008) or quantification of duodenal and milk FA flows (Glasser et al., 2008). Our results (48-57\%) are consistent with those obtained in ewes fed a similar TMR (51\%; Frutos et al., 2014) and most reports in cows consuming conserved forages and concentrates (approximately 48-64\%; Griinari et al., 2000; Karlengen et al., 2013; Leskinen et al., 2016). However, the inclusion of linseed oil in the ration of dairy sheep was associated with a lower percentage of endogenous milk OA (29\%; Toral et al., 2015b), whereas pasture diets increased its proportion in both cows and ewes (77 and 62\%, respectively; Kay et al., 2004; Bichi et al., 2012). Although the influence of different methodological approaches cannot be ruled out, this variation points to the importance of diet composition through its effect on rumen lipid metabolism (Jenkins et al., 2008; Shingfield et al., 2008b; Toral et al., 2016) and, consequently, on FA availability for mammary uptake. In line with this, a meta-analysis of the effects of lipid supplementation in cows (Glasser et al., 2008) estimated a wide range of milk OA originating from SA desaturation (49-94\%), suggesting that the contribution of SCD was proportional to substrate availability, whereas desaturation capacity did not seem to be a limiting factor. This hypothesis would be supported by the small differences in the percentage of SA desaturated to milk OA in the present study (47-50\%) and indirect estimations in ewes (48-57\%; Bichi et al., 2012; Frutos et al., 2014) and cows (approximately 40-55\%; Enjalbert et al., 1998; Karlengen et al., 2013; Leskinen et al., 2016). The lower value obtained by Toral et al. (2015b) in sheep fed linseed oil (35\%) might be speculated to be due to a negative effect of lipid supplementation, which is consistent with decreases in mammary SCD enzyme activity in dairy goats fed unsaturated plant lipids (Bernard et al., 2013). Given that standard enzymatic assays of $\Delta^{9}$-desaturase are based on the conversion of labeled SA into OA (e.g., Bickerstaffe and Annison, 1970; Bernard et al., 2005), our study also provides the first in vivo measurement of SCD enzyme activity in ewes.

\section{CONCLUSIONS}

This study provides the first assessment in dairy ewes of the uptake, $\Delta^{9}$-desaturation, and secretion into milk of a stable isotope tracer, namely ${ }^{13} \mathrm{C}$-labeled SA. In our experimental conditions, endogenous synthesis of milk OA, through SCD activity, is estimated to represent between 48 and $57 \%$ of total $\mathrm{OA}$ and derives from the conversion of 47 to $50 \%$ of SA. Given the very scant information on in vivo synthesis of milk FA deriving from $\Delta^{9}$-desaturation and the potential effect of the basal diet on measurements, further research under different dietary conditions is recommended to better understand the nutritional regulation of SCD activity and endogenous synthesis of milk FA in sheep and other ruminant species.

\section{ACKNOWLEDGMENTS}

This work was supported by the Spanish Ministry of Economy and Competitiveness (MINECO, Madrid; AGL2011-23700 and AGL2014-54587). P. G. Toral and D. Carreño benefit from a Juan de la Cierva research contract and an FPI predoctoral grant, respectively, from the MINECO. Co-funding by the European Regional Development Fund is also acknowledged. The authors thank L. Bernard and Y. Chilliard (INRA, Clermont-Ferrand, France) for helpful training in stable carbon isotope techniques during Toral's postdoctoral stay. They also thank R. Redondo and V. Peiró (Autonomous University of Madrid, Spain) for their contribution to $\mathrm{GC}-$-combustion isotope ratio MS analysis.

\section{REFERENCES}

Ankom. 2006a. Acid detergent fiber in feeds. Filter bag technique (For A2000, A2000I). Ankom Technology Method 8. Ankom Technology Corp., Macedon, NY.

Ankom. 2006b. Neutral detergent fiber in feeds. Filter bag technique (For A2000, A2000I). Ankom Technology Method 9. Ankom Technology Corp., Macedon, NY.

Annison, E. F., J. L. Linzell, S. Fazakerley, and B. W. Nichols. 1967 The oxidation and utilization of palmitate, stearate, oleate and acetate by the mammary gland of the fed goat in relation to their overall metabolism, and the role of plasma phospholipids and neutral lipids in milk-fat synthesis. Biochem. J. 102:637-647.

Bernard, L., C. Leroux, and Y. Chilliard. 2013. Expression and nutritional regulation of stearoyl-CoA desaturase genes in the ruminant mammary gland: Relationship with milk fatty acid composition. Pages 161-193 in Stearoyl-CoA Desaturase Genes in Lipid Metabolism. J. M. Ntambi, ed. Springer Science and Business Media, New York, NY.

Bernard, L., J. Mouriot, J. Rouel, F. Glasser, P. Capitan, E. PujosGuillot, J. M. Chardigny, and Y. Chilliard. 2010. Effects of fish oil and starch added to a diet containing sunflower-seed oil on dairy goat performance, milk fatty acid composition and in vivo $\Delta^{9}$-desaturation of $\left.{ }^{13} \mathrm{C}\right]$ vaccenic acid. Br. J. Nutr. 104:346-354.

Bernard, L., J. Rouel, C. Leroux, A. Ferlay, Y. Faulconnier, P. Legrand, and Y. Chilliard. 2005. Mammary lipid metabolism and 
milk fatty acid secretion in alpine goats fed vegetable lipids. J. Dairy Sci. 88:1478-1489.

Bichi, E., G. Hervás, P. G. Toral, J. J. Loor, and P. Frutos. 2013. Milk fat depression induced by dietary marine algae in dairy ewes: Persistency of milk fatty acid composition and animal performance responses. J. Dairy Sci. 96:524-532.

Bichi, E., P. G. Toral, G. Hervás, P. Frutos, P. Gómez-Cortés, M. Juárez, and M. A. de la Fuente. 2012. Inhibition of $\Delta^{9}$-desaturase activity with sterculic acid: Effect on the endogenous synthesis of cis-9 18:1 and cis-9,trans-11 18:2 in dairy sheep. J. Dairy Sci. 95:5242-5252.

Bickerstaffe, R., and E. F. Annison. 1970. The desaturase activity of goat and sow mammary tissue. Comp. Biochem. Physiol. 35:653665 .

Chilliard, Y., C. Delavaud, and M. Bonnet. 2005. Leptin expression in ruminants: Nutritional and physiological regulations in relation with energy metabolism. Domest. Anim. Endocrinol. 29:3-22.

Corl, B. A., L. H. Baumgard, D. A. Dwyer, J. M. Griinari, B. S. Phillips, and D. E. Bauman. 2001. The role of $\Delta^{9}$-desaturase in the production of cis-9, trans-11 CLA. J. Nutr. Biochem. 12:622-630.

Enjalbert, F., M. C. Nicot, C. Bayourthe, and R. Moncoulon. 1998. Duodenal infusions of palmitic, stearic or oleic acids differently affect mammary gland metabolism of fatty acids in lactating dairy cows. J. Nutr. 128:1525-1532.

Frutos, P., P. G. Toral, E. Ramos-Morales, K. J. Shingfield, A. Belenguer, and G. Hervás. 2014. Oral administration of cobalt acetate alters milk fatty acid composition, consistent with an inhibition of stearoyl-coenzyme A desaturase in lactating ewes. J. Dairy Sci. 97:1036-1046.

Glasser, F., M. Doreau, A. Ferlay, and Y. Chilliard. 2007. Technical note: Estimation of milk fatty acid yield from milk fat data. J. Dairy Sci. 90:2302-2304.

Glasser, F., A. Ferlay, M. Doreau, P. Schmidely, D. Sauvant, and Y. Chilliard. 2008. Long-chain fatty acid metabolism in dairy cows: A meta-analysis of milk fatty acid yield in relation to duodenal flows and de novo synthesis. J. Dairy Sci. 91:2771-2785.

Griinari, J. M., B. A. Corl, S. H. Lacy, P. Y. Chouinard, K. V. Nurmela, and D. E. Bauman. 2000. Conjugated linoleic acid is synthesized endogenously in lactating dairy cows by $\Delta^{9}$-desaturase. J. Nutr. 130:2285-2291

ISO. 1999a. Animal feeding stuffs - Determination of moisture and other volatile matter content. Standard 6496:1999. International Organisation for Standardisation (ISO), Geneva, Switzerland.

ISO. 1999b. Whole milk-Determination of milk fat, protein and lactose content - Guidance on the operation of mid-infrared instruments. Standard 9622:1999. International Organisation for Standardisation (ISO), Geneva, Switzerland.

ISO. 2002. Animal feeding stuffs - Determination of crude ash. Standard 5984:2002. International Organisation for Standardisation (ISO), Geneva, Switzerland.

ISO. 2009. Animal feeding stuffs-Determination of nitrogen content and calculation of crude protein content-Part 2: Block digestion and steam distillation method. Standard 5983-2:2009. International Organisation for Standardisation (ISO), Geneva, Switzerland.

Jenkins, T. C., R. J. Wallace, P. J. Moate, and E. E. Mosley. 2008. Board-invited review: Recent advances in biohydrogenation of unsaturated fatty acids within the rumen microbial ecosystem. J. Anim. Sci. 86:397-412.

Karlengen, I. J., O. Taugbøl, B. Salbu, A. H. Aastveit, and O. M. Harstad. 2013. Effect of different levels of supplied cobalt on the fatty acid composition of bovine milk. Br. J. Nutr. 109:834-843.

Kay, J. K., T. R. Mackle, M. J. Auldist, N. A. Thomson, and D. E. Bauman. 2004. Endogenous synthesis of cis-9, trans-11 conjugated linoleic acid in dairy cows fed fresh pasture. J. Dairy Sci. $87: 369-378$.
Leskinen, H., S. Viitala, M. Mutikainen, P. Kairenius, I. Tapio, J. Taponen, L. Bernard, J. Vilkki, and K. J. Shingfield. 2016. Ruminal infusions of cobalt EDTA modify milk fatty acid composition via decreases in fatty acid desaturation and altered gene expression in the mammary gland of lactating cows. J. Nutr. 146:976-985.

Loften, J. R., J. G. Linn, J. K. Drackley, T. C. Jenkins, C. G. Soderholm, and A. F. Kertz. 2014. Invited review: Palmitic and stearic acid metabolism in lactating dairy cows. J. Dairy Sci. 97:46614674 .

Meier-Augenstein, W. 1999. Applied gas chromatography coupled to isotope ratio mass spectrometry. J. Chromatogr. A 842:351-371.

Mosley, E. E., and M. A. McGuire. 2007. Methodology for the in vivo measurement of the $\Delta^{9}$-desaturation of myristic, palmitic, and stearic acids in lactating dairy cattle. Lipids 42:939-945.

Mosley, E. E., B. Shafii, P. J. Moate, and M. A. McGuire. 2006. cis-9, trans-11 conjugated linoleic acid is synthesized directly from vaccenic acid in lactating dairy cattle. J. Nutr. 136:570-575.

Shem-Tov, M., G. Ziv, A. Glickman, and A. Saran. 1997. Pharmacokinetics and penetration of marbofloxacin from blood into the milk of cows and ewes. Zentralbl. Veterinarmed. A 44:511-519.

Shingfield, K. J., S. Ahvenjärvi, V. Toivonen, A. Äröla, K. V. V. Nurmela, P. Huhtanen, and J. M. Griinari. 2003. Effect of dietary fish oil on biohydrogenation of fatty acids and milk fatty acid content in cows. Anim. Sci. 77:165-179

Shingfield, K. J., A. Äröla, S. Ahvenjärvi, A. Vanhatalo, V. Toivonen, J. M. Griinari, and P. Huhtanen. 2008a. Ruminal infusions of cobalt-EDTA reduce mammary $\Delta^{9}$-desaturase index and alter milk fatty acid composition in lactating cows. J. Nutr. 138:710-717.

Shingfield, K. J., M. Bonnet, and N. D. Scollan. 2013. Recent developments in altering the fatty acid composition of ruminant-derived foods. Animal 7(Suppl. 1):132-162.

Shingfield, K. J., Y. Chilliard, V. Toivonen, P. Kairenius, and D. I. Givens. 2008b. Trans fatty acids and bioactive lipids in ruminant milk. Adv. Exp. Med. Biol. 606:3-65.

Taugbøl, O., I. J. Karlengen, T. Bolstad, A. H. Aastveit, and O. M. Harstad. 2008. Cobalt supplied per os reduces the mammary $\Delta^{9}$-desaturase index of bovine milk. J. Anim. Sci. 86:3062-3068.

Toral, P. G., Y. Chilliard, and L. Bernard. 2012. Short communication: In vivo deposition of $\left[1-{ }^{13} \mathrm{C}\right]$ vaccenic acid and the product of its $\Delta^{9}-$ desaturation, $\left[1-{ }^{13} \mathrm{C}\right]$ rumenic acid, in the body tissues of lactating goats fed oils. J. Dairy Sci. 95:6755-6759.

Toral, P. G., Y. Chilliard, J. Rouel, H. Leskinen, K. J. Shingfield, and L. Bernard. 2015a. Comparison of the nutritional regulation of milk fat secretion and composition in cows and goats. J. Dairy Sci. 98:7277-7297.

Toral, P. G., G. Hervás, D. Carreño, and P. Frutos. 2016. Does supplemental 18:0 alleviate fish oil-induced milk fat depression in dairy ewes? J. Dairy Sci. 99:1133-1144

Toral, P. G., G. Hervás, and P. Frutos. 2015b. Reductions in milk $\Delta^{9}$-desaturation ratios to oral dosing of cobalt-acetate are accompanied by the downregulation of $S C D 1$ in lactating ewes. J. Dairy Sci. 98:1961-1971.

Tsiplakou, E., E. Flemetakis, C. Kalloniati, G. Papadomichelakis, P. Katinakis, and G. Zervas. 2009. Sheep and goats differences in CLA and fatty acids milk fat content in relation with mRNA stearoyl-CoA desaturase and lipogenic genes expression in their mammary gland. J. Dairy Res. 76:392-401.

Vernon, R. G. 1980. Lipid metabolism in the adipose tissue of ruminant animals. Prog. Lipid Res. 19:23-106.

Ziv, G., B. Kurtz, R. Risenberg, and A. Glickman. 1995. Serum and milk concentrations of apramycin in lactating cows, ewes and goats. J. Vet. Pharmacol. Ther. 18:346-351. 